\title{
Estimates of Net Capital Stock and Consumption of Fixed Capital for Australian States and Territories, 1990-2013*
}

\author{
Serguei Mikhailitchenko Being an important input for many economic \\ Holmes Institute, models and being widely used in economic \\ Brisbane, Australia decision making by the federal and regional \\ E-mail: government, capital stock data are not readily \\ smikhailitchenko@holmes.edu.au available at the sub-national level for most \\ countries, including Australia. The study closely \\ follows the methodology of the Australian \\ Bureau of Statistics and presents a complete set \\ of capital stock data for the states and territories \\ of Australia for the period 1990-2013. The \\ Keywords: robustness of the method is assessed by \\ regional capital stock, comparing the aggregated data by type of asset \\ perpetual inventory method estimates for the states, with the capital stock \\ Australia data by type of asset for Australia as a whole \\ published by the Australian Bureau of Statistics.
}

\section{Introduction}

Capital stock data is highly important for researchers in the areas of productivity and economic growth analysis. It allows a deeper insight into labour productivity and economic growth because, with capital stock data available, one can conduct multifactor productivity analysis to account for technological and institutional innovations as well as perform a detailed labour productivity analysis by decomposing output per unit of labour into output per unit of capital and capital-to-labour ratios. In the absence of official capital stock data for Australian states, researchers have to rely on the series developed by experimental studies. However, none of the previous studies has fully utilised the process used by the Australian Bureau of Statistics (ABS) for deriving the capital stock series and none of them has derived consumption of fixed capital data (COFC), which might be more useful for conducting productivity analysis because COFC, to some extent, accounts for the stock composition (OECD 2009: 61). \footnotetext{
2015 .

* A version of this paper was presented at the 2015 Australian Conference of Economists, Brisbane, 7-10 July
}

Regional Statistics, Vol 6, No 2. 2016: 114-128; DOI: 10.15196/RS06206 
The study reports the methodology employed for the estimation of stocks and flows of capital and presents a complete set of capital stock data for the six states and two territories of Australia for the period 1990-2013. The author departs from the simultaneous exit assumptions implicitly used by the previous studies, such as Levtchenkova and Petchey (2000), Louca (2003), and Mikhailitchenko, Nguyen and Smith (2005), and closely follows the Perpetual Inventory Model (PIM) process (ABS $5216.0,2012)$. One of the advantages of the approach used by the author is that, before estimating the series at a sub-national level, he looks at how the model works on highly aggregated investment data for Australia as a whole and compares his estimates with the NCS and COFC data published by the ABS. This permits the author, at least in the first approximation, to assess the quality of the estimates ${ }^{1}$.

Another advantage of this study is that it does not require any initial allocation of the national capital stock of each type among the states and territories at the beginning of the estimation period or between the public and the private sectors in each state. This is because the PIM process is applied directly to the data published by ABS Gross Fixed Capital Formation (GFCF). Without the need for two rounds of stock allocation, the method effectively removes one major source of statistical errors, which might be considered as an advantage over the methodology adopted by Mikhailitchenko, Nguyen, and Smith (2005).

Further, the author used age-and-type specific depreciation rates for all the series. In Mikhailitchenko et al. (2005), for example, the assets were depreciated using the national asset-specific depreciation rates, calculated by dividing COFC by NCS in relevant periods. This implies that all assets of a particular type, accumulated in the previous periods, are discounted at the same rate irrespective of the actual age of the existing assets in the stocks, which represents yet another source of error, the size of which positively correlates with the length of the service life of an asset. In the absence of other alternatives, utilising research conducted by Walters and Duppelsman (1985), ABS adopted a similar approach to discount pre-1948 NCS of Dwellings (DW). However, the errors in the latter can be expected to be of much smaller size than in Mikhailitchenko et al. (2005) because the relative weight of the pre-1949 items in the stock is very small due to the age of these assets and the small relative value of pre-1946 GFCF when compared to later years.

Finally, unlike previous research in the regional capital stock, this study applies not only the Age-efficiency and Age-price functions to the investment inflows but also the Survival function to account for stock retiring during the accounting period. In all the previous studies on NCS for Australian regions known to the author, the estimates were based on an assumption that all assets retire immediately after they reach the age equal to the mean useful service life, although the authors have not

${ }^{1}$ The estimates of NCS and COFC yielded satisfactory results. The results of the method pre-testing are not presented due to space and word count limits, but are available on request.

Regional Statistics, Vol 6, No 2. 2016: 114-128; DOI: 10.15196/RS06206 
stated this explicitly. For most stocks, the author used the Winfrey's S3 function, except for alternations and additions, where the $\mathbf{S 0}$ survival function was applied as specified in Winfrey (1938) and ABS (5216.0, 2012).

The study is the first to the author's knowledge that presents the estimates of COFC for Australian states and territories, which makes the whole set of capital stock data available for researchers. COFC might have an advantage over NCS in some research areas, such as the productivity analysis, because, being a part of the capital services flow, it accounts better for this variable in any given year and can be used to impute capital services series at user cost. Certainly, there is a significant difference in the flow of capital services between the value of a dollar invested in DW and the value of a dollar invested in Computer Software (CS) due to significant differences in the PIM parameters between these two types of assets.

Although the study closely follows the ABS PIM process, the aggregate estimates of total stocks and flows might differ from the data published by ABS due to the differences in the GFCF data available for the states and data available for Australia as a whole, in terms of the level of aggregation at which the PIM process is applied and the length of the available series. For example, ABS applied PIM separately for detached houses, residential units, and alterations and additions. In this study, the author was able to disaggregate alternations and additions from new dwellings, but not new dwellings by type. For the same reason, several stocks, such as cultivated biological products (CBR), intellectual property products (INTEL), and public (PUB) were estimated using aggregate GFCF data, despite the significant differences in PIM parameters between the stocks.

The rest of the article is organised as follows. Section II discusses the models applied for estimating capital stock series, while the discussion of data used for estimation is presented in Section III. Section IV gives the derived estimates of NCS and COFC for Australian states and territories and compares them with the data published by the Australian Bureau of Statistics. Section V provides the concluding comments.

\section{The model}

The study utilises the Perpetual Inventory Model (PIM) to estimate the NCS series, as Hulten (1990) describes it and ABS 5216.0 (2000).

$$
K_{t}^{i j}=K_{t-1}^{i j}+I_{t}^{i j}-D_{t}^{i j},
$$

where, $K_{t}^{i j}$ is NCS of asset type $\mathrm{i}$ in region $\mathrm{j}$ in period $\mathrm{t}$; $K_{t-1}^{i j}$ is NCS in period t -1 ; it accounts for accumulated NCS less retirement during the period; $I_{t}^{i j}$ is Gross Fixed Capital Formation (GFCF) (or investment) of asset type $\mathrm{i}$ in region $\mathrm{j}$ in period $\mathrm{t}$; $D_{t}^{i j}$ is Consumption of Fixed Capital (CFC) of asset type $\mathbf{i}$ in region $\mathbf{j}$ in period $\mathbf{t}$.

In this model, the NCS in the current period is estimated by adding GFCF to the NCS in the previous period less retirement and less depreciation in the current period.

Regional Statistics, Vol 6, No 2. 2016: 114-128; DOI: 10.15196/RS06206 
The investment made in the current period is added to the capital stock accumulated in the previous periods with zero depreciation. Depreciation applies only to the assets added in previous periods and at a vintage-specific rate. If equation (1) is used in default, as was the case, for example, by Mikhailitchenko, Nguyen and Smith (2005), we would need to initiate the series and derive $\boldsymbol{K}_{\boldsymbol{t}-\mathbf{1}}^{\boldsymbol{i j}}$ by going through at least two rounds of allocation of NCS of each type; first, between the states and territories, and, second, between the public and the private sectors for each state and for each type of asset. This inevitably results in an allocation error that does not diminish rapidly, especially for assets with long service lives, such as dwellings and non-dwelling construction. As an alternative, we can re-write $\boldsymbol{K}_{\boldsymbol{t}}^{\boldsymbol{i} \boldsymbol{j}}$ as a sum of GFCF discounted by the age-specific depreciation rates, $\boldsymbol{\delta}_{\mathrm{t}}$ in each year of service and by the age-specific retirement rates as per Winfrey's (1938) survival function.

$$
K_{t}^{i j}=\sum_{\tau=0}^{T} I_{t-\tau}^{i j}\left(1-\delta_{\tau}^{i j}\right)\left(1-\theta_{\tau}^{i j}\right),
$$

where, $\boldsymbol{I}_{\boldsymbol{t}-\boldsymbol{\tau}}^{\boldsymbol{i} \boldsymbol{j}}$ is the real value of investment of type $\mathbf{i}$ in a region $\mathbf{j}$ with the remaining service life of $\mathbf{t}-\tau ; \boldsymbol{\delta}_{\boldsymbol{\tau}}^{\boldsymbol{i} \boldsymbol{j}}$ is the accumulated loss of efficiency of an asset when it reaches the age $\tau ; \boldsymbol{\theta}_{\boldsymbol{\tau}}^{i \boldsymbol{j}}$ is the accumulated value of loss of assets due to their retirement from the stock.

As can be seen from the equation (2), PIM cumulates past investment flows, discounting them for loss in efficiency and outflows of assets from the stock due to retirement. A similar approach has been described in ABS (1351.0055.004, 2005: 22), with the only difference being, they applied price changes to the assets to obtain the net capital stock estimates in real terms. As these price deflators have already been applied to the investment data to produce GFCF series in chain volume measures, there is no need for the price factor in this place.

Apart from the investment data, the PIM, in the form of equation (2), requires parameters of the age-efficiency function for deriving vintage- and asset-specific depreciation rates and the survival function to account for the retired assets. The hyperbolic age-efficiency function is used to derive depreciation rates due to a decline in efficiency of an item, as shown in equation (3) below (ABS 5216.0, 2000).

$$
E_{t}=\frac{M-A_{t}}{M-b A_{t}},
$$

where, $\boldsymbol{E}_{\boldsymbol{t}}$ is the efficiency of a capital asset at a point of time t, $\boldsymbol{M}$ is the service life of an asset according to the Winfrey (1938) distribution, $\boldsymbol{A}_{\boldsymbol{t}}$ is the current age of an asset (equals $\mathrm{t}-\tau$ in equation (2)), $\mathbf{b}$ is the asset-specific efficiency reduction parameter.

Figure 1 below presents derived age-efficiency and age-price functions for dwellings as an example of the PIM processes used in this study. The calculated efficiency of an asset at each year between 0 and $\mathbf{T}$ gives the proportion of the initial potential of an asset to produce capital services, which is then used to construct the

Regional Statistics, Vol 6, No 2. 2016: 114-128; DOI: 10.15196/RS06206 
productive capacity function of an asset over its service life. The time-variant depreciation rate is then calculated as a percentage change in productive capacity in consecutive years.

Age-price and age-efficiency functions, dwellings

Figure 1

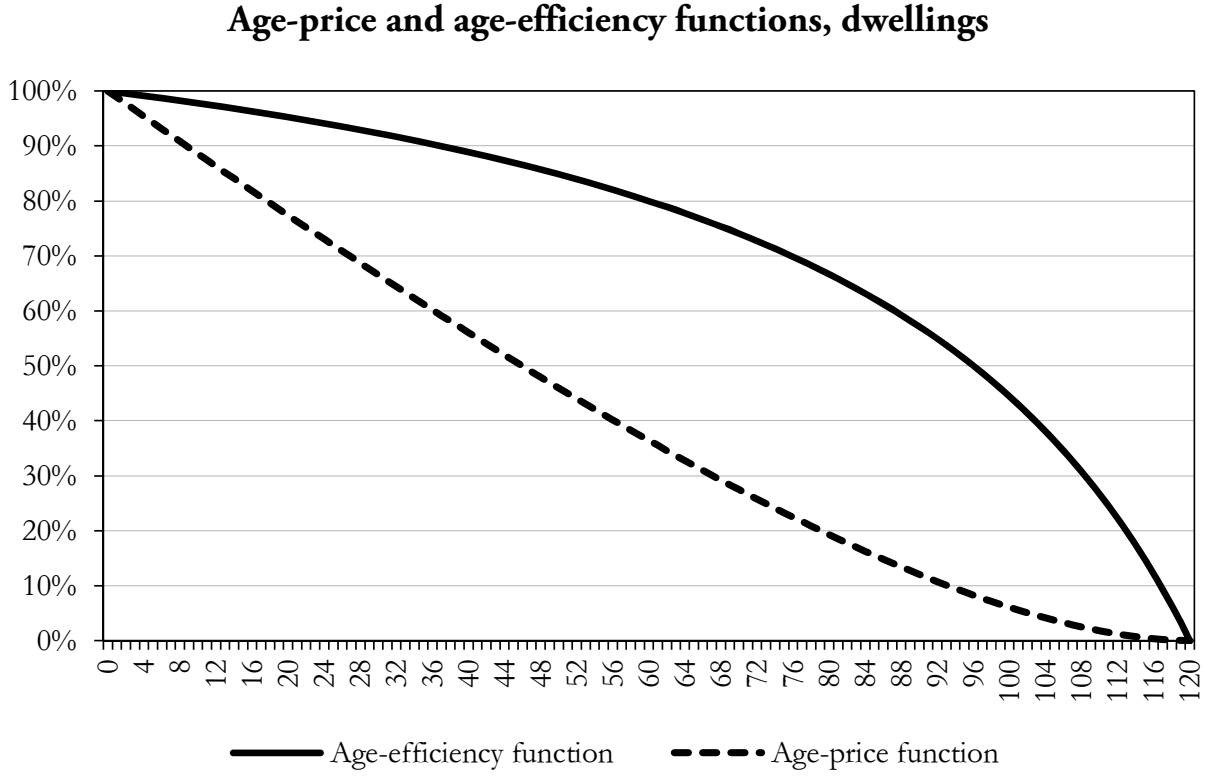

Source: Author's calculations.

Winfrey's survival functions are described as equation (4) below.

$$
F_{t}=F_{0}\left(1-\frac{T^{2}}{a^{2}}\right) m,
$$

where, $\boldsymbol{F}_{\boldsymbol{T}}$ is the proportion of the cohort retiring at the time $\mathrm{T}, \boldsymbol{F}_{\mathbf{0}}$ is the proportion of the cohort retiring at the mean asset service life, a the parameter that determines the time periods (e.g. $\mathrm{a}=10$ for deciles), $\mathbf{m}$ is the parameter that determines the flatness of the distribution.

Figure 2 presents the Survival function for new DW used in this study with the age of dwelling appearing on horizontal axis and the proportion of stock remaining in service on the vertical axis.

${ }^{2}$ For the sake of practicality, we used Winfrey's survival functions in a cumulative form. 
Winfrey's S3 survival function, dwellings

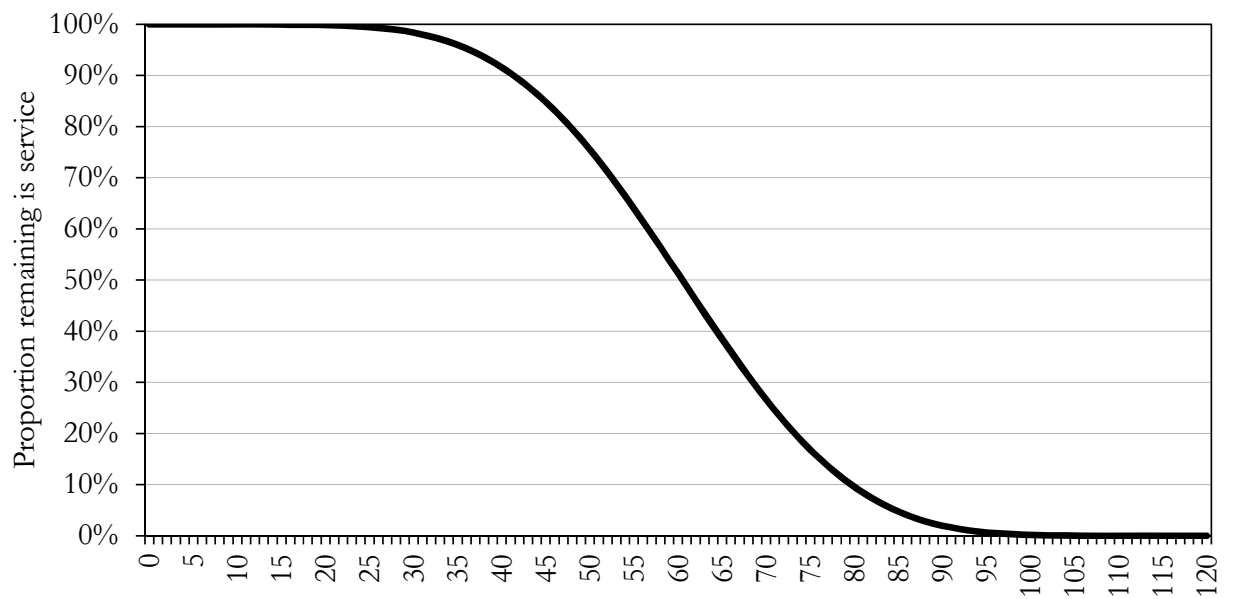

Age of dwelling

Source: Author's calculations.

Estimates of Consumption of Fixed Capital come as a by-product of the model. Equation (5) illustrates the process of the estimation of COFC.

$$
D_{t}^{i j}=\sum_{A_{t}=0}^{T} I_{t-\tau}^{i j}\left(\delta_{\tau}^{i j}-\delta_{\tau-1}^{i j}\right),
$$

This process specified by equation (5) uses the same parameters as per equation (2) and estimates COFC per asset as the change in the value of stock between two latest consecutive years.

Section III presents a discussion of GFCF data available as an input into the PIM process to derive NCS and COFC series at sub-national level.

\section{Data description and availability}

In most developed countries, data for physical capital are available at a national level. The ABS has been publishing annual NCS, GFCF and COFC data in chain-volume measures (CVM) and current prices for Australia as a whole since 1960 (ABS 5204.0), with the data disaggregated by type of asset (Table 56), by institutional sector (Table 57), and by industry (Table 58). However, with only a few exceptions, the same level of coverage does not apply to the data at sub-national level. In Australia, only GFCF by type of asset series are available for the states and territories. Official NCS and COFC estimates at sub-national level exist in only a few countries and are not available for Australian states. To the author's knowledge, only Canada has a complete set of data for the capital stock of its provinces (Statistics Canada 2012); in addition, India has capital stock estimates for some, but not for all its states.

Regional Statistics, Vol 6, No 2. 2016: 114-128; DOI: 10.15196/RS06206 
The published capital stock data by type of asset for Australia as a whole is of particular interest for this study because these data are used for preliminary testing and calibrating the models that are subsequently applied for deriving the corresponding regional series. GFCF data (ABS 5204.0) for nine types of assets, Dwellings (DW), Non-dwelling construction (NDC), Machinery and equipment (ME), Weapons (W), Cultivated biological resources (CBR), Research and development (R\&D), Mineral and petroleum exploration (PE), Computer software (CS), and Artistic originals (AO)), will allow for testing if equation (2) yields results that are comparable with the NCS official data from the same ABS publication.

It is challenging to test the model for the Ownership Transfer Costs (OTC) due to some discrepancies in the ABS manual (ABS 5216.0, page 376). While GFCF for this stock is supposed to depreciate over the period, as per the owner's plan to hold the asset, $\mathrm{ABS}$ gives the mean service life for OTC as equal to zero, which is mathematically impossible. In addition, the age-efficiency reduction parameter $\mathbf{b}$ is not specified in the ABS National Accounts Manual (5216.0, 2012), which makes equation (2) unidentified. Therefore, the maximum life of assets in OTC will be selected by trial and error for the length of the service life and the age-efficiency parameter under an assumption that most OTCs are for dwellings and non-dwelling construction assets.

The ABS has been publishing annual private GFCF data for the Australian states and territories in chain volume measures and current prices (ABS 5220.0) since 1990 and quarterly GFCF data (ABS 5206.0) since September 1985. The private sector data are disaggregated by type of asset, while the public sector series are disaggregated by the level of government (national, state, and local) and public corporations (commonwealth, state, and local). The same sources produce similar series for Australia as a whole with annual data starting from 1960 and quarterly data starting from September 1959.

Despite the fact that the annualised GFCF data now cover the periods of up to 26 years, the series still are too short for deriving NCS for assets with long service lives. For example, roads have a mean life span of up to 50 years, water and sewerage infrastructure can be used for up to 71 years, and private brick homes depreciated over 88 years, on average. This implies that some of the series must be over 150 years long and, for constructing net capital stocks series by using equation (2), will inevitably require some proxy inputs for the years where data are not available.

This study extended the work of Mikhailitchenko et al. (2005) and Mikhailitchenko (2008) in utilising proxy data by using other available series for DW. Using proxies should not be considered a significant deviation from the ABS methodology. For example, according to ABS 5216.0 (2012), an application of the normal S3 curve for survival function (Winfrey, 1938) for estimating NCS of houses implies that we need construction series longer than 150 previous years, while the first national account statistics, including building activity, became available only in the late 1940s (ABS 5216.0, 2000). This point has not been made explicitly clear in the manual; ABS refers

Regional Statistics, Vol 6, No 2. 2016: 114-128; DOI: 10.15196/RS06206 
to a range of sources (5216.0, page 370, clause 14.55), which implies that the value of stock added in early years is less reliable. Table 1 below summarises the GFCF data available for Australia as a whole and for its states and territories.

Table 1

\section{Availability of GFCF data}

\begin{tabular}{|c|c|c|c|}
\hline Type of asset & Australia as a whole & $\begin{array}{c}\text { Australian states and } \\
\text { territories }\end{array}$ & Proxies available \\
\hline Dwellings & $\begin{array}{l}\text { ABS } 5204.0 \text { Table 2: } \\
\text { annual, private, subdivi- } \\
\text { ded into dwellings, and } \\
\text { alternations and } \\
\text { additions, } 1960-2013 \\
\text { ABS 5204.0 Table 56: } \\
\text { annual, total of all } \\
\text { sectors, total subtypes, } \\
\text { 1960-2013 } \\
\text { ABS 5220.0: annual, } \\
\text { total all sub types, total } \\
\text { all sectors, 1960-2013 }\end{array}$ & $\begin{array}{l}\text { ABS 5220, annual, } \\
\text { private, dwellings, and } \\
\text { alterations and } \\
\text { additions, 1990-2013 } \\
\text { ABS 5206, quarterly, } \\
\text { private, dwellings, and } \\
\text { alterations and } \\
\text { additions, Sep 1985- } \\
\text { current }\end{array}$ & $\begin{array}{l}\text { ABS 8752, Number and } \\
\text { value of dwellings comp- } \\
\text { leted by state, quarterly, } \\
\text { private sector, and total, } \\
\text { Sep } 1969 \text {-current } \\
\text { ABS } 1300 \text { Year books } \\
\text { for the Australian states } \\
\text { and territories, annual, } \\
\text { number of new } \\
\text { dwellings constructed, } \\
\text { total all sectors, 1947- } \\
\text { current (except SA, } \\
\text { ACT, and NT) } \\
\text { ABS 3105, Table 1.11: } \\
\text { population, annual, } \\
\text { 1860-1994 }\end{array}$ \\
\hline $\begin{array}{l}\text { Ownership } \\
\text { transfer costs }\end{array}$ & $\begin{array}{l}\text { ABS 5204.0, annual, } \\
\text { total, total, 1960-2013 }\end{array}$ & $\begin{array}{l}\text { ABS 5220, annual, } \\
\text { private, total, 1990-2013 } \\
\text { ABS 5206, quarterly, } \\
\text { private, total all types, } \\
\text { Sep 1985-current } \\
\end{array}$ & $\begin{array}{l}\text { ABS 3105.0, Table 1.11: } \\
\text { population, annual, } \\
\text { 1860-1994 }\end{array}$ \\
\hline $\begin{array}{l}\text { Non-dwelling } \\
\text { construction }\end{array}$ & $\begin{array}{l}\text { ABS 5204.0 Table 2: } \\
\text { annual, private, sub- } \\
\text { divided into new build- } \\
\text { ings (1977-2013), new } \\
\text { engineering construction } \\
\text { (1977-2013), and } \\
\text { purchase of second hand } \\
\text { assets (1960-2013) and } \\
\text { total all sub types (1960- } \\
2013) \\
\text { ABS 5204.0 Table 56: } \\
\text { annual, total all sectors, } \\
\text { total sub types, 1960- } \\
2013\end{array}$ & $\begin{array}{l}\text { ABS 5206, annual, } \\
\text { private, sub-divided into } \\
\text { new buildings, new } \\
\text { engineering } \\
\text { construction, and } \\
\text { purchase of second } \\
\text { hand assets Sep 1985- } \\
\text { current } \\
\\
\text { ABS 5220, annual, } \\
\text { private, sub-divided into } \\
\text { new buildings, new } \\
\text { engineering construc- } \\
\text { tion, and purchase of } \\
\text { second hand assets } \\
\text { 1990-2013 }\end{array}$ & $\begin{array}{l}\text { ABS 3105, Table 1.11: } \\
\text { population, annual, } \\
\text { 1860-1994 }\end{array}$ \\
\hline
\end{tabular}

Regional Statistics, Vol 6, No 2. 2016: 114-128; DOI: 10.15196/RS06206 


\begin{tabular}{|c|c|c|c|}
\hline & & & (Continue \\
\hline Type of asset & Australia as a whole & $\begin{array}{c}\text { Australian states and } \\
\text { territories }\end{array}$ & Proxies available \\
\hline $\begin{array}{l}\text { Machinery } \\
\text { and } \\
\text { equipment }\end{array}$ & $\begin{array}{l}\text { ABS 5204.0 Table 2: } \\
\text { annual, private, sub- } \\
\text { divided into new assets } \\
\text { (1960-2013), net } \\
\text { purchase of second } \\
\text { hand items (1971-2013), } \\
\text { and total (1960-2013) } \\
\text { ABS 5204.0 Table 56: } \\
\text { annual, total all sectors, } \\
\text { total sub types, 1960- } \\
2013\end{array}$ & $\begin{array}{l}\text { ABS 5206, quarterly, } \\
\text { private, subdivided into } \\
\text { new assets, net purchase } \\
\text { of second hand assets, } \\
\text { and total, Sep 1985- } \\
\text { current } \\
\text { ABS 5220, annual, } \\
\text { private, sub-divided into } \\
\text { new assets, net purchase } \\
\text { of second hand assets, } \\
\text { and total, 1990-2013 }\end{array}$ & $\begin{array}{l}\text { ABS 3105, Table 1.11: } \\
\text { population, annual, } \\
\text { 1860-1994 }\end{array}$ \\
\hline $\begin{array}{l}\text { Weapons } \\
\text { systems }\end{array}$ & $\begin{array}{l}\text { ABS 5204.0, annual, } \\
\text { public, total all types, } \\
1960-2013\end{array}$ & Not available & Not available \\
\hline $\begin{array}{l}\text { Cultivated } \\
\text { biological } \\
\text { resources }\end{array}$ & $\begin{array}{l}\text { ABS 5204.0, annual, } \\
\text { total, total, 1960-2013 }\end{array}$ & $\begin{array}{l}\text { ABS 5220, annual, } \\
\text { private, total, 1990-2013 } \\
\text { ABS 5206, quarterly, } \\
\text { private, total all types, } \\
\text { Sep 1985-current } \\
\end{array}$ & No need for proxies \\
\hline $\begin{array}{l}\text { Intellectual } \\
\text { property } \\
\text { Products }\end{array}$ & \begin{tabular}{|l|} 
ABS 5204.0, Table 2: \\
annual, private, \\
disaggregated by RD, \\
MPE, CS, and AO, \\
1986-2013; total private \\
by type, 1960-2013 \\
ABS 5204.0, Table 56, \\
annual, total of all \\
sectors, disaggregated by \\
RD (1960-2013), MPE \\
(1960-2013), CS (1964- \\
2013) and AO (1972- \\
2013) \\
\end{tabular} & $\begin{array}{l}\text { ABS 5220, annual, } \\
\text { private, total all types, } \\
\text { 1990-2013 }\end{array}$ & $\begin{array}{l}\text { ABS 3105, Table 1.11: } \\
\text { population, annual, } \\
\text { 1860-1994 }\end{array}$ \\
\hline Public & \begin{tabular}{|l|} 
ABS 5204.0, Table 2: \\
annual, public, \\
disaggregated by public \\
corporations \\
(Commonwealth; state \\
and local; total public \\
corporations); General \\
government (national \\
(defence; non-defence; \\
and total) and state and \\
local; total general \\
government), total \\
public, 1960-2013
\end{tabular} & $\begin{array}{l}\text { ABS 5220, annual, public, } \\
\text { disaggregated into Public } \\
\text { Corporations and } \\
\text { General Government, } \\
\text { 1990-2013 } \\
\text { ABS 5206, quarterly, } \\
\text { public, disaggregated } \\
\text { into Public Corporations } \\
\text { and General Govern- } \\
\text { ment (National and State } \\
\text { and Local; total General } \\
\text { Government), and total } \\
\text { public, 1990-2013 }\end{array}$ & $\begin{array}{l}\text { ABS 3105, Table 1.11: } \\
\text { population, annual, } \\
\text { 1860-1994 }\end{array}$ \\
\hline
\end{tabular}

Regional Statistics, Vol 6, No 2. 2016: 114-128; DOI: 10.15196/RS06206 
As can be seen from Table 1, GFCF data are available for Australia, which allows for pre-testing the models as per equations (2) and (5) before applying them for estimation of NCS and COFC at the sub-national level. The issues associated with the level of aggregation of GFCF data for the states are also visible from Table 1. At the state level, GFCF appears either as private investment flows disaggregated by asset type or as data series for public GFCF, disaggregated into public corporations and general government without providing details of the stock composition.

For DW, the author is using the value of residential work done (ABS 8752.0, 2013 and ABS 1300, various years) as a proxy for GFCF for the period 1948-1985. The author finds that GFCF data exhibit higher volatility than population growth numbers. In addition, given the slow depreciation of DW, the size of the errors will be larger if the population is used as a proxy for GFCF in years when the residential work data are available. The percentage changes in the value of building work done has been selected on the basis that the old series for the value of residential work done in current prices have a significantly steeper slope that chained GFCF series. However, the annual percentage changes produce a very good fit for the proxies into the real GFCF data. For years prior to 1948 , the author chose to use population as a proxy. ${ }^{3}$

Further, difficulties are related to the Intellectual Property Products (Intel) series. At the state level, these data are published as a total for all type of assets within a stock, while Australian data are disaggregated into the following four subcomponents: Research and Development (R\&D), Mineral and Petroleum Exploration (MPE), Computer Software (CS), and Artistic Originals (AO). This represents a challenge due to the significant differences in the PIM parameters for the sub-components in Intel. For example, the mean service lives in MPE is 35 years, while AO are depreciated within the first 2 years, on average. In this study, the author used the national weighted average of each sub-type in Intel to determine the PIM parameters.

Given the issues discussed above, the estimates of the derived series should be treated with caution, especially the INTEL series. Now, the published and proxy data will be used in Section 4 to evaluate the performance of the model for Australia as a whole.

\section{Estimating Net Capital Stock and CFC for Australian states and territories}

In this section, the author applies equations (2) and (5) to derive NCS and COFC series by type of asset for Australian states and territories and reports the estimates of NCS and COFC by type of asset for the Australian states and territories. The PIM processes adopted in this study applies the Age-Efficiency and the Winfrey's survival

${ }^{3}$ Mikhailitchenko (2008) used a similar approach; graphs showing the proxy series are available on request.

Regional Statistics, Vol 6, No 2. 2016: 114-128; DOI: 10.15196/RS06206 
functions, simultaneously, as per equations (2) and (5). Table 2 presents the PIM parameters used for estimating capital stock data in this study.

Table 2

Parameters of Perpetual Inventory Model (PIM)

\begin{tabular}{l|c|c|c}
\hline & $\begin{array}{c}\text { Winfrey Survival } \\
\text { function }\end{array}$ & Mean service life & $\begin{array}{c}\text { Efficiency } \\
\text { reduction } \\
\text { parameter }\end{array}$ \\
\hline Dwellings & S3 & 60 & 0.750 \\
Alternations and additions & S0 & 35 & 0.500 \\
Ownership transfer costs & S3 & 13 & 0.500 \\
Non-dwelling construction & S3 & 35 & 0.750 \\
Machinery and equipment & S3 & 12 & 0.500 \\
Cultivated biological products & S3 & 6 & 0.500 \\
Intellectual property products & S3 & 13 & 0.135 \\
Public assets & S3 & 40 & 0.500
\end{tabular}

Source: Author's estimates.

Similarly, the public investment data is given by the ABS at a highly aggregated level, which implies the same process of guessing the PIM parameters. We assume that the efficiency reduction parameter and the mean service life for the Public assets are 0.75 and 30, respectively. The New Dwellings were assumed to have an average service life of 60 years, while the Alternations and Additions and Non-Dwelling Construction assets remain in service for 35 years, on average. The efficiency reduction parameters for these assets are assumed to be equal to 0.75 for dwellings and non-dwelling construction and 0.5 for the Alterations and Additions.

For Machinery and Equipment, the mean service life and efficiency reduction parameters were 12 and 0.5, respectively. The Cultivated Biological Resources serve for 6 years, on average, and follow the age-efficiency function with $b$ equal to 0.5 . For Intellectual Property Products, the author used 13 years and 0.135 for the mean service life and the efficiency reduction parameters, respectively.

The estimated capital stock data for Australian states and territories by asset type are provided in Tables A.1 to A.8 in Appendix. Figure 3 provides the comparison between the aggregate estimates of NCS and COFC by ABS and this study. The author presents the data 'as is' without adjusting the data at the base year of 2012 to illustrate the degree of reliability. As can be seen from this figure, the error term is largest in 1990 (6.7\%), which gradually diminishes until $2008(2.2 \%)$ and then increases again until 2013 (4.1\%) (The estimated capital stock data for Australian states and territories by asset type are provided in Tables A.1 to A.8 in Appendix on the Regional Statistics's website.)

Regional Statistics, Vol 6, No 2. 2016: 114-128; DOI: 10.15196/RS06206 
Net Capital Stock, total, Australia 1990-2013

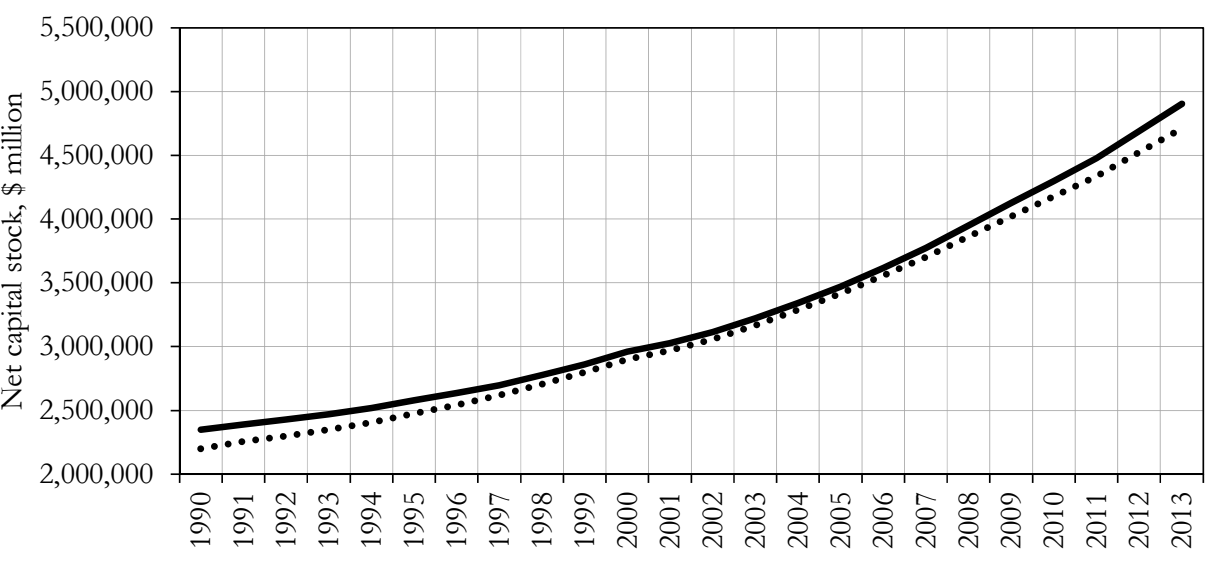

Source: Author's estimates.

Figure 4 presents the estimates of total COFC for Australia as a sum of COFC of all types for all states. As can be seen from the figure, the estimates of COFC are not as accurate as in the case of NCS. This study overestimates the ABS series by $13 \%$ in 1990 and underestimates by $17 \%$ in 2013, which indicates to the author that some further research effort is required to correct the COFC series for errors wherever it is possible.

Figure 4

Consumption of Fixed Capital, total, Australia 1990-2013

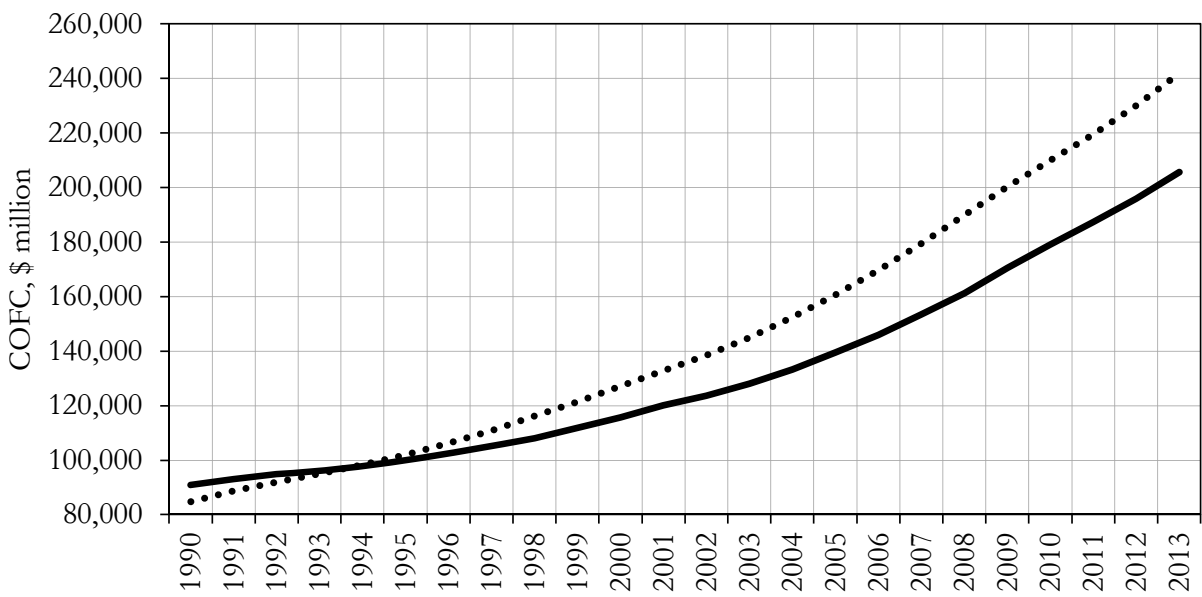

Estimated

-........ABS

Source: Author's estimates.

Regional Statistics, Vol 6, No 2. 2016: 114-128; DOI: 10.15196/RS06206 
Figure 5 presents regional Net Capital Stock data in 1990 and 2013 in terms of NCS per capita. As can be seen from the graph, the amount of physical capital per head of the population has grown significantly between 1990 and 2013 for all states and Australia as a whole.

Figure 5

Net Capital Stock per capita, Australia and states, 1990 and 2013

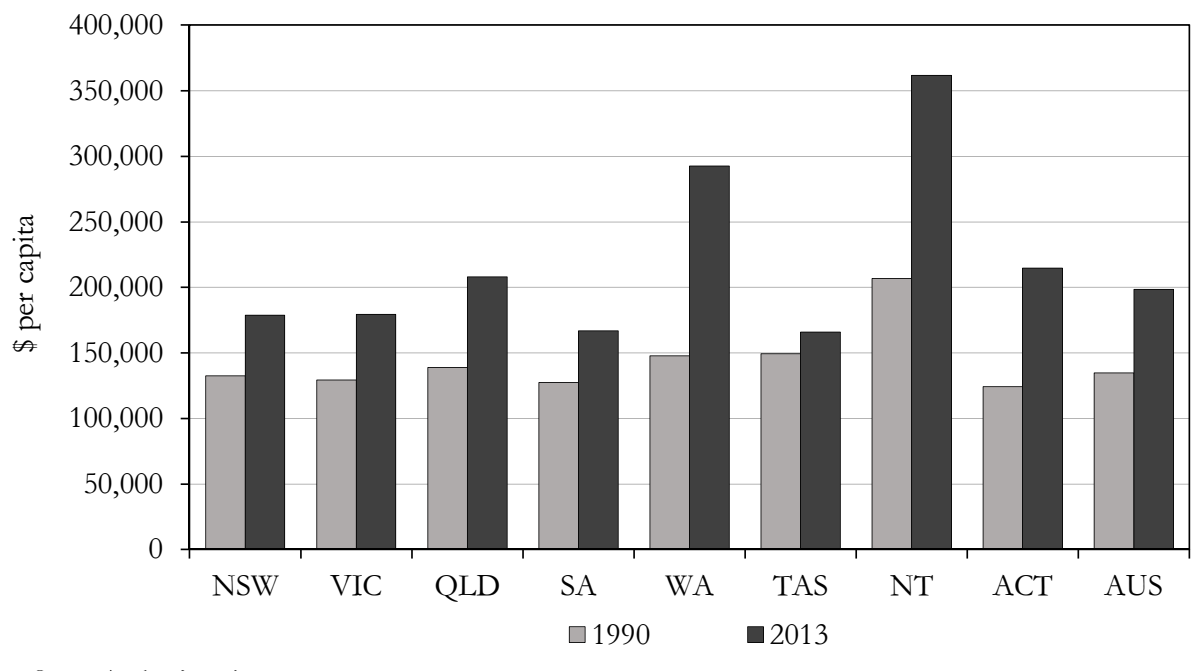

Source: Author's estimates.

The highest level of capital per capita was in the mining states of Queensland, Western Australia, and Northern Territory in 1990 and remains such in 2013. The lowest per capita NCS is in traditionally underperforming states of South Australia and Tasmania. Further research into the regional economic performance in Australia can be conducted by utilising the developed series by type of asset. For example, the value of public NCS per capita in Tasmania has not changed between 1990 and 2013, which might indicate that a lack of public infrastructure is hindering the faster economic growth of this state.

Although there are differences between the NCS values in this study and the corresponding estimates by ABS, it should be kept in mind that chained series do not necessarily sum up, with the exception of the base year, which is 2012 in this case $e^{4}$. The largest percentage error for NCS is $-3.6 \%$, which might be considered as nonsignificant given the issues with the lack of investment data at the state level.

${ }^{4}$ ABS 5216.0 (2012), page 70.

Regional Statistics, Vol 6, No 2. 2016: 114-128; DOI: 10.15196/RS06206 


\section{Conclusion}

The study provided the series for the Net Capital Stock and CFC for Australian states and territories for the period 1990-2013. The series were derived through the PIM process that closely followed procedures used by the ABS for deriving NCS and COFC series for Australia as a whole. There are several advantages of this study compared to the previous attempts, with the first one being the removal of initial allocation of the capital stock among the states and the sectors within the states. In addition, this study extends the previous work by applying the survival function to the assets and effectively removing another error term present in all previous estimates at sub-national level for Australia.

There are several obvious caveats present in this study. Despite following the ABS methodology as closely as possible, a number of PIM parameters have been selected based on educated guess for some of the GFCF series, such as Dwellings, Intellectual Property Products, and the Public sector, because the series are highly aggregated compared to the data used by ABS for Australia as a whole. The significant differences in the PIM parameters for different types of assets might cause an error that is impossible to assess in this study in the absence of micro data.

Although this type of error is also related to the aggregation level of the data, in the absence of micro GFCF data for Machinery and Equipment, it is impossible to determine the PIM parameters in any reliable way. This is because of the changing composition of this stock due to the growth in proportional holdings of assets with relatively short service lives, such as computers and peripherals, and a gradual decrease in the proportion of assets, such as cars and machinery.

The NCS and COFC estimates for Australian states and territories provided by this study facilitates spatial analysis of the capital availability in Australia as well as utilisation of this data for other types of analyses, such as the multifactor productivity analysis. The results should be treated with caution due to the sensitivity of the estimates to the selected parameters of the Perpetual Inventory Model.

\section{REFERENCES}

Australian Bureau OF STATISTICS (various years): Australian System of National Accounts Cat. no. 5204.0, ABS, Canberra.

Australian Bureau of Statistics (2013): Australian National Account: National Income, Expenditure and Product, Cat. no. 5206.0, ABS, Canberra.

Australian Bureau of Statistics (2012): Australian System of National Accounts: Concepts, Sources and Methods $3^{\text {rd }}$ ed., Cat. no. 5216.0, ABS, Canberra.

Australian Bureau of Statistics (various years): Australian Year Book Cat. no. 1301.0, ABS, Canberra.

Australian Bureau of Statistics (various years): New South Wales Year Book Cat. no. 1300.1, ABS, Canberra.

Regional Statistics, Vol 6, No 2. 2016: 114-128; DOI: 10.15196/RS06206 
Australian Bureau of Statistics (various years): Victorian Year Book, Cat. no. 1300.2, ABS, Canberra.

Australian Bureau of Statistics (various years): Queensland Year Book Cat. no. 1301.3, ABS, Canberra.

Australian Bureau of Statistics (various years): South Australian Year Book Cat. no. 1301.4, ABS, Canberra.

Australian Bureau of Statistics (various years): Western Australian Year Book Cat. no. 1300.5, ABS, Canberra.

Australian Bureau of Statistics (various years): Tasmanian Year Book Cat. no. 1301.6, ABS, Canberra.

Australian Bureau OF StATistics (various years): Northern Territory at a Glance Cat. no. 1304.7, ABS, Canberra.

Australian Bureau of Statistics (various years): Australian Capital Territory Business Indicators Cat. no. 1303.8, ABS, Canberra.

AUSTRALIAN BUREAU OF STATISTICS (2005): Estimating Industry-Level Multifactor Productivity for the Market-Sector Industries in Australia: Methods and Experimental Results Australia, Cat. No. 1351.0055.004, ABS, Canberra.

Australian Bureau of Statistics (2006): Population Projections, Australia, Cat. no. 3202.0, ABS, Canberra.

Australian Bureau of Statistics (various years): Building Activity, Australia, Cat. no. 8752.0, ABS, Canberra.

Australian Bureau of Statistics (various years), Australian National Accounts: State Accounts Cat. no. 5220.0, ABS, Canberra.

Hulten, C. (1990): The Measurement of Capital In: Berndt, E. R.-TripletT, J. (eds.) Fifty Years of Economic Measurement pp. 119-152., NBER, Washington, D.C.

Levtchenkova, S.-Petchey, J. (2000): Regional Capital Stock Data for Australia Australian Economic Review 33 (2): 193-197.

LoucA, J. (2003): Multifactor Productivity and Innovation in Australia and Its States In: Williams, C.-Smith, C.-Draca, M. (eds) Productivity and Regional Economic Performance in Australia pp. 99-138., Queensland Government, Brisbane.

Mikhailitchenko, S.-NguYen, D. T.-SMith, C. (2005): Estimates of Capital Stocks for the States and Territories of Australia, 1985-2004 Economic Analysis and Policy 35 (1/2): 1-22.

Mikhailitchenko, S. (2008): Australian Housing Market: Price Dynamics and Capital Stock Growth $\mathrm{PhD}$ thesis, Griffith University, Brisbane.

OECD (2009): Measuring Capital. OECD Manual. $2^{\text {nd }}$ edn., OECD, Brussels.

STATISTICS CANADA (2012): Investment, capital stock and capital services of physical assets, by North American Industry Classification System (NAICS), annual (Dollars) (downloaded: 23 August 2012)

http://www5.statcan.gc.ca/cansim/a34? lang=eng\&id=3830025\&search

TypeByValue $=1 \&$ mode $=$ tableSummary $\& \mathrm{p} 2=35$

Walters, R.-Dippelsman, R. (1985): Estimates of Depreciation and Capital Stock Australian Bureau of Statistics, Occasional Paper No. 1985/3, ABS, Canberra.

WINFrey R. (1938): Statistical Analysis of Industrial Property Retirements Iowa State College of Agricultural and Mechanic Arts, Ames, Iowa.

Regional Statistics, Vol 6, No 2. 2016: 114-128; DOI: 10.15196/RS06206 